\title{
Ben Golder
}

Foucault and the Politics of Rights. Stanford: Stanford University Press, 2015, 246 pp.

In Foucault and the Politics of Rights, Ben Golder takes on a topic that has recently received much attention in the political theory/Foucault scholarship world, that of Michel Foucault's ostensible turn to rights in late commentary. What do Foucault's references to rights say about the consistency and relevance of Foucault's views on politics and law, and what are their implications for the continued viability of Foucaultian critique? Golder clearly and convincingly responds to critics who would find in this late work a relinquishing of critique or collaboration with a quiescent liberalism. Very carefully drawing on Foucault's writings and lectures, Golder lucidly articulates Foucault's view of critique and shows how even when Foucault endorses a "right to suicide" or argues against the death penalty, he considers rights discourse to be a tactic, deployed (or not) within a broader strategy of political aims.

If the critics need responding to, then Golder has indeed done so and has done so very well. Golder's readings are scholarly, painstaking, and correct. His argument is an invaluable contribution to discussions that seek Foucault's legacy in theory (rather than looking, as some might, in the directions that Foucault's students have taken). If I myself would have preferred to hear less about Foucault, more about rights, and something about law, then that is to come dangerously close to asking for a different book.

Golder's first chapter constitutes an excellent and pedagogically useful introduction to Foucault. The explanation of critique as destabilizing and opening up possibilities is clear and true to Foucault's texts. The pastoral "counterconduct" which makes use of pastoral practices to contest pastoral governance that Golder finds "buried in Foucault's historical presentation of the somewhat marginal practices of some medieval Christian circles in his 1978 College course" (56) offers a convenient-and original-model for Golder's later discussion, in the fourth and final chapter, of the way Foucault uses rights. Foucault's rights-assertion "both functions to remake and contest relations with others while establishing a particular relation to a conception of the rights holder herself" (57).

Two short intermediate chapters show how Foucault's comments about Iran and Poland, and in Geneva to mark the creation of the International Committee against Piracy, do not recenter the liberal subject, but rather, as in his earlier work, raise questions about the "human" (75-8). Here Golder might have distinguished more carefully between various "humans"-those of philosophical rights, of domestic or state legal rights, and of international law. Rather than doing so, Golder moves on to the way that "rights claiming" and "regulatory control" are flip sides of rights discourse; they constitute the "ambivalence of rights." Foucault's evocations of freedom and friendship, Golder contends, offer a context within which counterconduct, which makes use of or points out such ambivalence, can occur.

Chapter 4 then turns explicitly to two examples of counterconduct, using the distinction between tactic and strategy, where tactic refers to the particular thing that you use; strategy to a grander plan. Golder nicely traces this distinction from Clausewitz through Marx and critical theory. Golder also explains how the "right" 
to suicide is not just the right of an autonomous subject for Foucault, but is related to an ethics or care of the self that serves as counterconduct in the face of the control that a biopolitical state would exercise over bodies. For Foucault, the right to suicide not only counters state power, but also interestingly offers an opportunity to "meditate" ethically on one's condition and to "rethink our lives" as other than sovereign subjects or individuals (133-7). Golder then shows how Foucault refuses to use the language of human rights in the context of the death penalty. Foucault instead embeds his critique of capital punishment in a broader account of juridicalpenal institutions, Golder argues, because addressing capital punishment via rights-claiming threatens to refine the penal apparatus and to strengthen the biopolitical state.

Golder ultimately concludes with what he calls an impossible set of questions (161). He says that "it is very much a contested question whether human rights provide the best means with which to grapple with the world's social, economic, and political problems" (160-1). This may be a question for some, but Golder's book itself has nevertheless successfully made the case against there being any single "best means" with which to grapple with the world's problems. Golder asks, "Can all claims be made in the language of human rights?" (161) although his argument has quite directly suggested that they cannot be. Some of the questions that follow-about the limits of human rights and their reappropriation-have indeed not been answered and can have no universal answer. Golder's concluding claim that one must not look to Foucault for answers or for what Foucault would do today thus does not completely mesh with the book's overall argument: that for Foucault, as Golder convincingly puts it, "it is a question of strategy whether any given rights framework permits a margin for political contestation and critical subversion" (161).

\author{
Marianne Constable \\ University of California at Berkeley \\ constable@berkeley.edu
}

